Volume 5 Issue 4, December 2018

\title{
Implementation Of Mudharaba Agreement In PT. Bank Tabungan Negara (BTN) Tbk. Sharia Business Unit (SBU) Branch Of Semarang
}

\author{
Fiana Zahroh Suciani ${ }^{1}$, Bonar Setyantono ${ }^{2}$ and Aryani Witasari ${ }^{3}$
}

Abstract. This study aims to conduct a study that jurisdiction over on mudharabah at. Bank Tabungan Negara (BTN) Tbk. SBU Branch of Semarang and to know mudharabah implementation constraints on PT. Bank BTN Tbk. SBU Branch of Semarang and how to overcome them. The research method used is normative, the source of the data used are secondary data gathered through identification and inventory of legislation and library books interviews as supporting data, then the data is analyzed by qualitative normative method.

Based on the results of research and discussion we concluded that the Agreement Mudharabah is a partnership contract by PT. Bank Tabungan Negara (BTN) Tbk. Sharia Business Unit (SBU) Branch of Semarang to customers of PT. Bank Tabungan Negara (BTN) Tbk. Sharia Business Unit (SBU) Branch of Semarang as shahibul maal finance, hundred percent of funds to the client (mudharib). Implementation mudharabah in PT. Bank Tabungan Negara (BTN) Tbk. Sharia Business Unit (SBU) the new branch also complies with Islamic legal theory and the theory of legal certainty.

Keywords: Mudharabah; Islamic Banking.

\section{Introduction}

Understanding Notary regulated in Article 1 paragraph (1) of Act No. 2 of 2014 concerning Notary. Article 15 Paragraph (1) and (2) of Act No. 2 of 2014 concerning Notary mention about the authority of the Notary. Article 3 of Act No. 2 of 2014 concerning Public Notary states have other powers stipulated in the legislation. ${ }^{4}$

Revisions in the field of banking-related legislation, which is more specifically related to the Islamic economy Islamic banking is the enactment of Act No. 21 of 2008 concerning Islamic Banking. Strictly speaking, with the enactment of Act No. 21 of 2008 concerning Islamic Banking, the banking practices of the national system is no longer just recognize dual-banking system, but rather emphasize that the existence of banks with Islamic principles in parallel with conventional banks. ${ }^{5}$

Mudharaba is a contract between two parties where one party called rab al-mal (investor) entrust money to a second party, called mudharib, for the purpose of running your own business. In Islamic banking, the agreement Mudharaba has expanded not only between the bank and the customer but involves three parties, namely the depositors as sahib al-mal, bank as agent / arrenger that serves as

\footnotetext{
1 Student of Master of Notary Law Universitas Islam Sultan Agung email: fianazahroh@yahoo.co.id

2 Students of Master of Law, Faculty of Law, Universitas Islam Sultan Agung email setyantonobonar@yahoo.com

${ }^{3}$ Lecturer in Faculty of Law UNISSULA Semarang

${ }^{4}$ Law No. 2 of 2014 concerning on Notary.

5 Khudari Ibrahim "Penerapan Prinsip Mudharabah Dalam Perbankan Syariah Mudharabah Principle of Banking Products" Jurnal Magister Ilmu Hukum Universitas Mataram,Vol. II No. 4 (2014) url : http://jurnallius.ac.id/ojs/index.php/jurnalIUS/article/download p. 43.
} 
intermediary, and entrepreneurs as mudharib requiring fund. Mudharabah the basis of profit and loss sharing principle is one alternative that is right for Islamic financial institutions to avoid the system of interest (interest free) which by some scholars considered the same as usury is forbidden. ${ }^{6}$ Based on these descriptions, the author is interested in conducting a study entitled Assessment of Juridical Mudharabah at PT. Bank Tabungan Negara (BTN) Tbk Sharia Business Unit (SBU) Branch of Semarang.

Based on the background described above, the authors take the following main issues: 1) How the study of juridical mudharabah at. Bank BTN Tbk. SBU Branch of Semarang? 2) Is the implementation constraints mudharabah at. Bank BTN Tbk. SBU Branch of Semarang and how to solve it?

\section{Research methods}

The approach used in this study on "Juridical Studies on Mudharabah at PT. Bank BTN Tbk. SBU The new branch "is a normative juridical study to examine secondary data in the form of positive legal materials and discussion of the problem is qualitative (not shaped figure).

The study was based on research literature but to supplement the data obtained from the research literature, no supporting data. This is done because the research literature for details need to be supported with data from PT. Bank BTN Tbk. SBU Branch of Semarang. The research literature to obtain secondary data and research at PT. Bank BTN Tbk. SBU Branch of Semarang as supporting data. ${ }^{7}$

Specification used in this research is descriptive research specifications. Descriptive research is a study which is intended to provide the data as thoroughly as possible with humans, state or other symptoms, as well as the state of the object only describes the problem without any intention to take generally accepted conclusion that relate and explain the implementation Mudharabah at PT. Bank BTN Tbk. SBU Branch of Semarang. ${ }^{8}$

Source material scientific writings are secondary data, ie legal material obtained by researchers from the research literature and documentation, which is the result of research and treatment of others, which is already available in the form of books or documentation that is usually provided in the library or private investigators, the library of legal materials described on theory, views experts opinion and so on, which is an ingredient of thinking and behaving in a collection of legal materials. It aims to obtain objective results from this study of secondary data will be divided and broken down into three parts, namely Legal Materials Primary, Secondary Legal Materials, and Materials Tertiary Law.

Primary legal materials are materials that are sourced from the legislation that has to do with Sharia Banking Law, ie the Qur'an; Al-Hadith; Code of Civil law; Compilation of Islamic Law; Law Compilation of Islamic Economics; Act No. 21 of 2008 concerning Islamic Banking; Set of fatwas.Secondary Legal Materials, the legal materials that provide an explanation for the primary legal materials, consisting of bome sharia contract or agreement made by the Bank in particular at PT. Bank BTN Tbk. SBU Branch of Semarang and books the work of experts, reports the results of research, seminars, symposia, workshops, papers, dissertations and other scientific works related

\footnotetext{
${ }^{6}$ Mahmudatus Sa'diyah dan Meuthiya Athifa Arifin "Mudharabah Dalam Fiqih dan Perbankan Syari'ah" Jurnal Hukum Vol. 1 No.2 :http://journal.stainkudus.ac.id/index.php/equilibrium/article/download p. 303.

7 Soerjono Soekanto and Sri Mamuji, 1986 Pengantar IImu Hukum Jakarta UI Press p. 55.

${ }^{8}$ Ibid. p.98.
} 
to sharia agreement.Tertiary legal materials are materials that provide guidance to primary and secondary legal material, comprising: Law Dictionary and Encyclopedia. ${ }^{9}$ In addition to secondary data, this study also derived from data obtained from PT. Bank BTN Tbk. SBU Branch of Semarang. Data obtained from research at PT. Bank BTN Tbk. SBU the new branch as the supporting data from secondary data obtained from the literature. Research Location namely PT. Bank BTN Tbk. SBU Branch of Semarang. Tools and How to research, the methods used are interviews, a dialogue conducted by the interviewer to obtain information from interviewees (interviewed).

This study used data collection methods as follows: Secondary Data and Supporting Data.

\section{Results and Discussion}

\subsection{Juridical Study of Mudharabah On PT. Bank BTN Tbk. SBU Branch of Semarang}

The theory of Islamic law applied that theory in complexu which Receptie statedby Gibb. According to this theory, for Muslims Islamic law in full effect because she had converted to Islam although in practice there are deviations. The teachings of Islam are still less attention including Islamic teachings on economics and banking to avoid usury. ${ }^{10}$

In addition to Islamic Legal Theory, the theory used is the Theory of Rule of Law. There are four things that relate to the meaning of the rule of law. First, that the law is positive, it means that he is prevailing invitation, Second, that the law is based on facts. Third, that the facts should be formulated in a clear way so as to avoid confusion and easy to administer. Fourth, positive law should not be changed frequently. ${ }^{11}$

Islamic economic law is a law that is used to enforce sharia in the Indonesian economy. Islamic economics include Islamic economics micro and Islamic economics macro. Assessing macro economics is to examine the society as a whole and not individuals or companies. While micro economy is discussed only in terms of contractual relations between debtors and creditors. ${ }^{12}$

Agreement in terms of Indonesian called a contract, is a logical consequence of social relations in human life. Islamic banking is a container that holds transactions growing agreement that community. Agreement in Islamic banking is a dimension that is urgent, and can determine whether the bank is pure apply Islamic principles or not, as stated in the Decree of the Board of Directors of BI No.32 / 34 / KEP / dir dated May $12,1999,{ }^{13}$

Nextin terms of the presence or absence of compensation, the contract is divided into two parts, namely the contract tabarru and tijarah contract. Agreement Tabarru are all sorts of agreements concerning not for profit transaction (transaction-profit). This transaction is essentially not a business transaction to seek commercial gain.

\footnotetext{
${ }^{9}$ Ronny Hanitijo Soemitro 1990 Metodologi Penelitian dan Jurimetri Jakarta Ghalia Indonesia p. 12-13

10 Juhaya S. Praja 2011 Teori Hukum dan Aplikasinya Bandung CV Pustaka Setia p. 81.

11 Satjipto Rahardjo 2006 Hukum Dalam Jagat Ketertiban Jakarta UKI Press p. 135-136.

12 Edy Sismarwoto 2009 Pembagian Warisan Menurut Kompilasi Hukum Islam Semarang Pustaka Magister p. 1-2.

${ }^{13}$ Abdul Rokhim 2014 Konstruk dan Model Pembiayaan Musyarakah Mutanaqishah Di Bank Syariah. Jember : UINSU. Jurnal Syariah Vol. 1 No. 2. url: http://jurnal.uinsu.ac.id/index.php/humanfalah/article/download. p. 46-47.
} 
Agreement tijarah are all sorts of agreements concerning for profit transaction. This contract is used for profit, therefore this agreement are commercial. One is mudharabah. ${ }^{14}$

Mudharaba is a partnership between two parties in which the first party (sahib al-mal) provides the funds and the second party (mudharib) is responsible for managing the business. Advantages responsibility for managing the business. Profits distributed according to the ratio of earnings that have been agreed in advance, when the loss sahib al-mal will lose some rewards of hard work and managerial skills during the project.

Verses of the Qur'an that can be used as a reference base of Mudharabah contract transaction is QS.Al-Muzammil: 20 QS.Al-Jum'ah: 10 and QS.Al-Baqarah: 198. Hadith Rasul which can be used as the basic reference of Mudharabah contract transaction is "narrated by Ibn Abbas that Hadrat Abbas when providing funds to its business partners Mudharaba, it requires that the funding would not be brought across the sea, down the valley are dangerous, or buy livestock berparu- vomit, if it violates the rules in question are responsible for the fund. Disampaikannyalah these requirements to the Prophet. and that he introduced it (Hadith quoted by Imam Alfasi in Majma Azzawaid 4/161)".

Terms of Mudharaba, capital must be clearly stated in number in case of capital in the form of goods then the goods are to be priced in the price during the currency in circulation (or the like), capital must be in cash and not credit, capital must be submitted to mudharib, to enable it doing business, profit sharing should be expressed in percentage of profit that may be generated later, the percentage ratio agreement must be reached through negotiations and set forth in the contract, and a new profitsharing can be done after mudharib return all (or most) of capital to Rab al-mal. Margin Financing is revenue sharing between the customer and the bank must be established before the signing of the financing. Ratio can be determined as of 70:30, $60:^{15}$

Islamic Bank in implementing the Mudharaba contract determines the amount of capital loaned to the business to be run. Generally, the funds provided in cash (cash), it allows the bank to continue to supervise and manage the business. ${ }^{16}$ The end of Mudharabah financing agreement. In practice, the expiration of the agreement of financing is the Debtor has paid the full financing it has received and Creditors cancel the financing agreement. ${ }^{17}$

On June 17, 2008 has passed the Banking Act of Sharia enactment in the State Gazette conducted July 16, 2008, in the form of Act No. 21 of 2008 concerning Islamic Banking. ${ }^{18}$ Understanding Islamic Banking under Article 1 paragraph (1) of Act No. 21 of 2008 concerning Islamic Banking is everything concerning the Islamic Banking and

\footnotetext{
14 Nofinawati 2014 Akad Dan Produk Perbankan Syariah Padangsidimpuan : IAIN. Jurnal

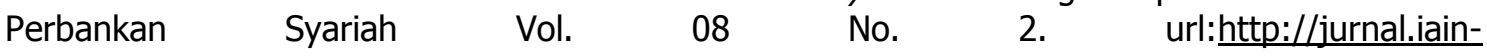
padangsidimpuan.ac.id/index.php/F/article/download.,p. 220-223.

15 Muhammad 2000 Sistem dan Prosedur Operasional Bank Syariah Yogyakarta:UII Press. p. 13-17.

16 Ibid. p. 103-106.

17 Warkum Sumitro 2004 Asas-Asas Perbankan Islam dan Lembaga-Lembaga Terkait Jakarta : PT. RajaGrafindo Persada. p. 96-101.

${ }^{18}$ Abdul Ghofur Anshori 2010 Pembentukan Bank Syariah Melalui Akuisisi dan Konversi (Pendekatan Hukum Positif dan Hukum Islam). Yogyakarta:UII Press Yogyakarta. p. 16-18.
} 
Sharia Business Unit, covering institutional, business activities, as well as the manner and process of carrying out its business activities. ${ }^{19}$

Mudharabah at PT. Bank Tabungan Negara (BTN) Tbk. Sharia Business Unit (SBU) The new branch has been in accordance with the understanding Mudharaba, both within Act No. 21 of 2008 concerning Islamic Banking and the Law Compilation of Islamic Economics (KHES). In the sense that that is in essence that the Mudharaba namely cooperation between shahibul maal with mudharib where sharing according to the agreement of the parties.

Implementation Mudharabah at PT. Bank Tabungan Negara (BTN) Tbk. Sharia Business Unit (SBU) Branch of Semarang when viewed from the Islamic legal theory is appropriate. That is because PT. Bank Tabungan Negara (BTN) Tbk. Sharia Business Unit (SBU) has implemented a new branch of the Islamic legal theory in mudharabah to impose Islamic law. Implementation mudharabah when viewed from the theory of legal certainty are also appropriate. Mudharabah has been regulated in Act No. 21 of 2008 concerning Islamic Banking so that the implementation mudharabah already have legal certainty because it has been set in writing by the legislation.

\subsection{Implementation Constraints Of Mudharabah}

Constraints on the implementation of the general mudharabah is less supervision on the implementation mudharabah; the bank is very cautious towards financing is, so not all businesses can apply for financing; and the lack of information on the Mudharabah in society, so not many people know about Mudharaba.

From some of the obstacles mentioned above, the authors provide a solution, among others, for the future, there needs to educate more people about so that people know about the Mudharaba; the need to supervise the implementation of mudharabah so mudharib not in default; and provides the opportunity for people who want to apply for a bank of financing and must oversee that mudharib not in default.

\section{Closing}

\subsection{Conclusion}

From the discussion above, it is concluded that Mudharabah at PT. Bank Tabungan Negara (BTN) Tbk. Sharia Business Unit (SBU) the new branch has been in accordance with the understanding Mudharaba, both within Act No. 21 of 2008 concerning Islamic Banking and the Law Compilation of Islamic Economics (KHES). Implementation Mudharabah at PT. Bank Tabungan Negara (BTN) Tbk. Sharia Business Unit (SBU) Branch of Semarang when viewed from the Islamic legal theory and the theory of legal certainty is appropriate.

\subsection{Suggestion}

The author gives some suggestions, that people still need legal counseling on Mudharaba so either from the government, the Islamic banks, as well as from academics need to provide legal counseling on Mudharaba. On the implementation mudharabah which the Islamic bank provides funds sertus percent to mudharib or customers need for maximum supervision order mudharib not in default.

\footnotetext{
${ }^{19}$ Act No. 21 of 2008 concerning on Islamic Banking.
} 


\section{Bibliography}

[1] Anshori Abdul Ghofur 2010 Pembentukan Bank Syariah Melalui Akuisisi dan Konversi (Pendekatan Hukum Positif dan Hukum Islam) Yogyakarta: UII Press Yogyakarta.

[2] Muhammad 2000 Sistem dan Prosedur Operasional Bank Syariah Yogyakarta: UII Press.

[3] Praja Juhaya S. 2011 Teori Hukum dan Aplikasinya Bandung : CV Pustaka Setia.

[4] Satjipto Rahardjo 2006 Hukum Dalam Jagat Ketertiban Jakarta : UKI Press.

[5] Edy Sismarwoto 2009 Pembagian Warisan Menurut Kompilasi Hukum Islam Semarang : Pustaka Magister.

[6] Soerjono Soekamto 1986 Pengantar Penelitian Hukum.Jakarta : UI Press.

[7] Soerjono Soekanto dan Sri Mamuji 1986 Pengantar Penelitian Hukum Jakarta : UI Press.

[8] Ronny Hanitijo Soemitro 1990 Metodologi Penelitian dan Jurimetri Jakarta: GhaliaIndonesia.

[9] Warkum Sumitro 2004 Asas-Asas Perbankan Islam dan Lembaga-Lembaga Terkait Jakarta : PT. RajaGrafindo Persada.

[10] Code of Civil law

[11] Compilation of Islamic Law

[12] Law Compilation of Islamic Economics

[13] Act No. 2 of 2014 concerning Notary

[14] Act No. 21 of 2008 concerning Islamic Banking

[15] Khudari Ibrahim 2014 Penerapan Prinsip Mudharabah Dalam Perbankan Syariah Mudharabah Principle of Banking Products. Jurnal Magister Ilmu Hukum $\begin{array}{llllll}\text { Universitas Mataram } & \text { Vol. }\end{array}$ :http://jurnallius.ac.id/ojs/index.php/jurnalIUS/article/download.

[16] Putri Apria Ningsih 2014.Akad-Akad Perbankan Syariah Pertukaran Dan Percampuran. Riau : Universitas Islam Indafri. Jurnal Syariah, Vol. 2, No. 1. url : http://ejournal.fiaiunisi.ac.id/index.php/syariah/article/download.

[17] Nofinawati 2014 Akad Dan Produk Perbankan Syariah. Padangsidimpuan : IAIN. Jurnal Perbankan Syariah, Vol. 08, No. 2. url:http://jurnal.iainpadangsidimpuan.ac.id/index.php/F/article/download.

[18] Mahmudatus Sa'diyah dan Meuthiya Athifa Arifin. 2013. Mudharabah Dalam Fiqih dan Perbankan Syariah. Jurnal Hukum Vol. 1, No.2. url : http://journal.stainkudus.ac.id/index.php/equilibrium/article/download.

[19] Abdul Rokhim 2014 Konstruk dan Model Pembiayaan Musyarakah Mutanaqishah Di Bank Syariah. Jember : UINSU. Jurnal Syariah, Vol. 1, No. 2. url : http://jurnal.uinsu.ac.id/index.php/humanfalah/article/download. 